\title{
Small scale broiler farming at Santhia upazilla of Pabna District of Bangladesh
}

\author{
F Sultana* ${ }^{1}$, H Khatun ${ }^{2}$, A I slam ${ }^{1}$ \\ ${ }^{1}$ Department of Poultry Science; ${ }^{2}$ Department of Animal Science, Bangladesh Agricultural University, \\ Mymensingh 2202, Bangladesh
}

\begin{abstract}
The experiment was conducted for profiling the existing broiler farming at Santhia upazilla under Pabna District during the period from February to March, 2012. Data were collected using an interview schedule from 50 randomly selected respondents who were involved in broiler farming. In this study out of 50 respondents $60 \%$ were engaged in agriculture, 36\% businessman and $4 \%$ were in services. About $48 \%$ respondents had small size farms (100-500 birds), 40\% had medium (501-1000 birds) and remaining were large size (1001-2000 birds). Most of the respondents reared Cobb-500 strain, those were purchased from Kazi Farms Ltd. Out of 50 respondents $30 \%$ took necessary suggestions from the experienced farmers, $90 \%$ farmers regularly vaccinated their broilers and $70 \%$ farmers taken short training on broiler farming. About $78 \%$ respondents considered market weight as $1.5 \mathrm{~kg}$ per bird, whereas the rest $22 \%$ sold broiler weighing about $1.8 \mathrm{~kg}$ per bird. Most of the respondents $(64 \%)$ sold broiler at 30-33 d of age and about $80 \%$ respondents marketing their broiler at 110-115 taka per kg live bird. About 36\% respondents had production cost approximately 90-95 taka per kg bird. In this study, about 36\% respondents reported more marketing age of birds, 32\% reported higher cost of production and $30 \%$ reported lack of training facilities. In conclusion, the result of present study could be considered useful to farmers and researchers to identify the overall problems and their remedies on management and marketing related to broiler production.
\end{abstract}

Key words: Broiler production, farming system, Pabna district

Bangladesh Animal Husbandry Association. All rights reserved. Bang. J. Anim. Sci. 2012. 41 (2): 116-119

\section{Introduction}

Small-scale poultry production has developed in a large number of developing contries around the world as an important source of earning for the rural poor. It is growing rapidly and successfully becoming a leading industry in Bangladesh. Islam (2003) stated that there is no doubt that exciting times lie ahead for the Bangladesh poultry industry. Akter and Uddin (2009) reported that poultry industry as a fundamental part of animal production is committed to supply the nation a cheap source of good quality nutritious animal protein in terms of meat and egg. Poultry meat alone contributes $29 \%$ of the total meat production in the country (BBS, 2001) and it can efficiently and rapidly fulfill the gap of protein requirement in the shortest possible time. This sector is crucially important in the context of agricultural growth and improvement of diets of people in Bangladesh.

Profitability of broiler production involves proper assessment of demand, planning the size of the activity, possible integration of activities to bring down the cost of production, foresight into market

*Corresponding Author: Iyzuh@yahoo.com price situations, and prudent assessment of costbenefits and finally the rate of returns in the activity. These situations vary from country to country and even between regions of a country. Thus, to explore the insight of the broiler farming of a particular area of the country, it is essential to understand the characteristics of the farmers, farm size and socio-economic status of the farmers to make the business profitable. Therefore, the present study was undertaken to identify the existing management system of broiler farm, problems related with broiler production and their potential solutions.

\section{Materials and Methods}

The present study was conducted to investigate the existing broiler farming status at Santhia upazilla under Pabna District during the period from February to March, 2012. Data were collected through an interview schedule involving 50 respondents who were involved in broiler farming. Respondents were randomly selected from different parts of the upazilla for collecting data to address the objectives. In this study 50 respondents were interviewed to find out their 
socio-economic condition. The selected characteristics included age, occupation, total annual income, annual income from poultry, farm size, rearing system, sources of day old chick, type of feed used, feed price, marketing age, marketing price, farmer's problem and recommendations.

Data were collected following the direct interviews and making frequent personal visits. Interviews were normally conducted in the market or in respondent's house during their leisure time. Major focal points of the interview were the general information about the farmers, number of farms and birds, management of broiler farm, feed source, fundamental idea on rearing and marketing of broiler. Problems and probable solutions related to broiler production were also focused. The collected data were analyzed statistically by using simple statistical tools like average and percentage through SPSS software.

\section{Results and Discussion}

\section{Socio-economic background}

Number and percentage distribution of respondents according to their age group, family size and occupation are shown in Table 1 . It is revealed that the majority $(60 \%)$ of the respondents were in the middle age (31-50 years), 34\% respondents were young (upto 30 years) and the remaining were old age (above 50 years). Aganga et al. (2000) conducted study in the Southern region of Botswana reported that maximum farmers involved in poultry farming remain within the range of 35-50 years. Educational background of the 50 respondents, as observed in the present study, $20 \%$ were within the elementary level, $70 \%$ were secondary and remaining $10 \%$ were within the intermediate level, suggesting that the maximum farmers handling broiler farms were within the secondary level of education. The results are consistent with the previous report of Rahman et al. (2002).

Out of the 50 respondents $60 \%$ were involved in agriculture, $36 \%$ in businessman and $4 \%$ in services as their main profession. Being a part of agriculture based economy it was not surprising that $60 \%$ of poultry farmers choose their main profession as agriculture, which was highest. Previous reports of Jabber and Green (1983), Miah (1990) and Karim (2001) showed that farmer's main occupation was agriculture. In case of annual income of farmers, $46 \%$ of the respondents belong to medium level of income (100001-150000 taka), $34 \%$ and $20 \%$ of the respondents were in low and high level of incomes, respectively.

Factors involved with broiler farming system by the respondents are shown in Table 2. About $48 \%$ respondents had small size farms (100-500 birds), $40 \%$ had medium (501-1000 birds) and remaining were large size (1001-2000 birds). About $80 \%$ respondents reared Cobb-500 and rest reared Ross, Hubbard and Starbro strain. These results are almost similar to the previous report of Hauque (2005). Singh and Sharma (2003) also estimated that maximum farmers choose Cobb500 for their better production.

Table 1. Distribution of respondents according to their age group, education level, occupation and annual income of farmers

\begin{tabular}{|c|c|c|c|}
\hline Parameters & Categories & $\begin{array}{l}\text { No. } \\
\text { respondent } \\
(n=50)\end{array}$ & $\begin{array}{l}\% \\
\text { respondent } \\
(n=50)\end{array}$ \\
\hline \multirow{3}{*}{ Age } & $\begin{array}{l}\text { Young age } \\
\text { ( } \leq 30 \text { yrs) }\end{array}$ & 17 & 34 \\
\hline & $\begin{array}{l}\text { Middle age } \\
\text { (31-50 yrs) }\end{array}$ & 30 & 60 \\
\hline & $\begin{array}{l}\text { Old age } \\
(>50 \text { yrs) }\end{array}$ & 3 & 6 \\
\hline \multirow{3}{*}{$\begin{array}{l}\text { Education } \\
\text { level }\end{array}$} & $\begin{array}{l}\text { Low educated } \\
\text { (1-5 class) }\end{array}$ & 10 & 20 \\
\hline & $\begin{array}{l}\text { Medium } \\
\text { (6-9 class) }\end{array}$ & 35 & 70 \\
\hline & $\begin{array}{l}\text { Higher } \\
\text { (10-11 class) }\end{array}$ & 5 & 10 \\
\hline \multirow{3}{*}{ Occupation } & Agriculture & 30 & 60 \\
\hline & Businessman & 18 & 36 \\
\hline & Services & 2 & 4 \\
\hline \multirow{3}{*}{$\begin{array}{l}\text { Annual } \\
\text { income } \\
\text { of farmers } \\
\text { (taka) }\end{array}$} & $\begin{array}{l}\text { Low income } \\
(50000- \\
100000)\end{array}$ & 17 & 34 \\
\hline & $\begin{array}{l}\text { Medium } \\
\text { income } \\
(100001- \\
150000)\end{array}$ & 23 & 46 \\
\hline & $\begin{array}{l}\text { High income } \\
(151000- \\
240000)\end{array}$ & 10 & 20 \\
\hline
\end{tabular}

\section{Factors associated with broiler farming}

In this study, most of the farmers (90\%) vaccinated their birds regularly against infectious disease. Rahman (2004) reported that 70\% broiler farmers vaccinated birds regularly and 


\section{Small scale broiler farming}

$30 \%$ did not practice vaccination. About $30 \%$ respondents received suggestion from experienced farmers, $10 \%$ did not take any suggestion and remaining taken suggestion from veterinary surgeons, technical graduates or dealers. About $70 \%$ respondents received short training on broiler management whereas about $30 \%$ did not take any training at all. The result is same as Rahman et al. (2003), who reported that among 50 respondents in the study area, 70\% had training on broiler farming from local YTC (Youth Training Center), Upazilla Livestock Office, NGO's and different broiler farming related agencies. In the present study out of 50 respondents, $80 \%$ purchased broiler chick from Kazi Farm Ltd. and $98 \%$ used ready-made feed for broiler rearing.

Table 2. Factors associated with broiler farming system

\begin{tabular}{|c|c|c|c|}
\hline Parameters & Categories & $\begin{array}{l}\text { No. res- } \\
\text { pondents } \\
(n=50)\end{array}$ & $\begin{array}{l}\% \text { Res- } \\
\text { pondents } \\
(n=50)\end{array}$ \\
\hline \multirow{3}{*}{ Farm size } & $\begin{array}{l}\text { Small } \\
\text { (100-500 birds) }\end{array}$ & 24 & 48 \\
\hline & $\begin{array}{l}\text { Medium } \\
\text { (501-1000 birds) }\end{array}$ & 20 & 40 \\
\hline & $\begin{array}{l}\text { Large } \\
\text { (1001-2000 birds) }\end{array}$ & 6 & 12 \\
\hline \multirow{4}{*}{$\begin{array}{l}\text { Name of } \\
\text { strain }\end{array}$} & Cobb-500 & 40 & 80 \\
\hline & Ross & 5 & 10 \\
\hline & Hubbard & 3 & 6 \\
\hline & Starbro & 2 & 4 \\
\hline \multirow{2}{*}{ Vaccination } & Practiced & 45 & 90 \\
\hline & Not practiced & 5 & 10 \\
\hline \multirow{5}{*}{ Counselor } & None & 5 & 10 \\
\hline & Veterinarian & 10 & 20 \\
\hline & $\begin{array}{l}\text { Experienced } \\
\text { farmer }\end{array}$ & 15 & 30 \\
\hline & $\begin{array}{l}\text { Technical } \\
\text { graduates } \\
\end{array}$ & 10 & 20 \\
\hline & Dealer & 10 & 20 \\
\hline \multirow{2}{*}{$\begin{array}{l}\text { Training on } \\
\text { broiler } \\
\text { rearing }\end{array}$} & Received & 35 & 70 \\
\hline & Not received & 15 & 30 \\
\hline \multirow{3}{*}{$\begin{array}{l}\text { Sources of } \\
\text { broiler } \\
\text { chick }\end{array}$} & Kazi Farm Ltd. & 40 & 80 \\
\hline & Nourish Poultry & 5 & 10 \\
\hline & CP Company Ltd. & 5 & 10 \\
\hline \multirow[t]{2}{*}{ Feed use } & Ready made & 49 & 98 \\
\hline & Hand made & 1 & 2 \\
\hline
\end{tabular}

\section{Production cost and marketing price of live broilers}

Factors associated with cost of production and marketing of live broiler are shown in Table 3. About $50 \%$ respondents purchased day-old chicks at 31-33 taka per chick whereas $80 \%$ respondents purchased feed 32-35 taka per kg.

About $78 \%$ respondents considered market weight as $1.5 \mathrm{~kg}$ per bird, whereas the rest $22 \%$ sold broiler weighing about $1.8 \mathrm{~kg}$ per bird. Almost similar result was observed by Hauque (2005), who found $1.5 \mathrm{~kg}$ average market weight per bird. Perry et al. (1999) also found average market weight per bird was $1.10 \mathrm{~kg}$. It ranged from 1.07 $\mathrm{kg}$ to $1.70 \mathrm{~kg}$ per bird.

Majority of the respondents $(64 \%)$ sold broiler at 30-33 d of age and about $80 \%$ respondents marketing their broiler at 110-115 taka per $\mathrm{kg}$ live bird. About $80 \%$ respondents marketed broiler with a price of 110-115 taka per kg bird, rest $40 \%$ marketed broiler at 120-125 taka per kg bird. Karim (2001) showed that there was a wide range of fluctuation in market price, which might be due to the fact that farmers, while selling the bird, were captivated by the middleman. Out of the 50 respondents $36 \%$ respondents had production cost 90-95 taka per $\mathrm{kg}$ live bird and $32 \%$ respondents had highest production cost at 101-104 taka per $\mathrm{kg}$ live bird which is in close agreement with the results previously reported by Hauque (2005).

Table 3. Factors associated with cost of broiler production and marketing

\begin{tabular}{|c|c|c|c|}
\hline Parameters & Categories & $\begin{array}{l}\text { No. res- } \\
\text { pondents } \\
(n=50)\end{array}$ & $\begin{array}{l}\% \text { Res- } \\
\text { pondents } \\
(n=50)\end{array}$ \\
\hline \multirow{3}{*}{$\begin{array}{l}\text { Price } \\
\text { (Taka/chick) }\end{array}$} & $26-30$ & 20 & 40 \\
\hline & $31-33$ & 25 & 50 \\
\hline & 34-35 & 5 & 10 \\
\hline \multirow{2}{*}{$\begin{array}{l}\text { Feed price } \\
(\text { Taka/kg) }\end{array}$} & $32-35$ & 40 & 80 \\
\hline & $36-40$ & 10 & 20 \\
\hline \multirow{2}{*}{$\begin{array}{l}\text { Market weight } \\
(\mathrm{kg} / \text { bird) }\end{array}$} & 1.50 & 39 & 78 \\
\hline & 1.80 & 11 & 22 \\
\hline \multirow{2}{*}{$\begin{array}{l}\text { Marketing age } \\
\text { (d) }\end{array}$} & $30-33$ & 32 & 64 \\
\hline & $34-36$ & 18 & 36 \\
\hline \multirow{2}{*}{$\begin{array}{l}\text { Marketing price } \\
\text { (Taka/kg live } \\
\text { bird) }\end{array}$} & $110-115$ & 40 & 80 \\
\hline & $120-125$ & 10 & 20 \\
\hline \multirow{3}{*}{$\begin{array}{l}\text { Production cost } \\
\text { (Taka per kg } \\
\text { bird) }\end{array}$} & 90-95 & 18 & 36 \\
\hline & $96-100$ & 16 & 32 \\
\hline & 101-104 & 16 & 32 \\
\hline \multirow{3}{*}{$\begin{array}{l}\text { Annual income } \\
\text { from broiler } \\
\text { farm } \\
\text { (Taka/year) }\end{array}$} & $\begin{array}{l}19200- \\
50000\end{array}$ & 11 & 22 \\
\hline & $\begin{array}{l}51000- \\
100000 \\
\end{array}$ & 27 & 54 \\
\hline & $\begin{array}{l}100001- \\
144000\end{array}$ & 12 & 24 \\
\hline
\end{tabular}

In present study out of 50 respondents $54 \%$ respondents earned 51000-100000 taka per year from broiler farm, whereas the rest $22 \%$ and $24 \%$ 
respondents earned 19200-50000 and 100001144000 taka per year, respectively. Hauque (2005) showed that the annual income from poultry farming ranged between 12988.80 to 276120.00 taka per year, which is very close to the result of the present study.

\section{Problems and suggestions on rearing and marketing of broiler}

Depending on demand, price variation of day old chick and lack of quality chicks, availability and quality of vaccines, high price of feed, lack of quality feed and training facilities were the major problems for broiler production faced by farmers in the study area. In this study, about $36 \%$ respondents reported more marketing age of birds, 32\% reported higher cost of production and $30 \%$ reported lack of training facilities. The farmers also suggested that the government should fix and control the price to a limit up to stability so that they can get deserved price. Availability of commercial day old chicks with reasonable market price should be ensured. Sufficient training programs on broiler farming should be arranged, so that the farmers can keep themselves up to date. For indemnity, safety, and security, poultry insurance system should be introduced immediately.

\section{Conclusion}

The result of this study area will be useful for farmers and researchers to identify the overall problems and their remedies on feeding, management and marketing related to broiler production. The findings may therefore pass some valuable information for proper management of broiler in rural area of Bangladesh.

\section{References}

Aganga AA, Omphile UJ, Malope $\mathrm{P}$, Chabanga $\mathrm{CH}$, Motsamai GM and Motsumi LG (2000). Traditional poultry production and commercial broiler alternatives for smallholder farmers in Botswana. Livestock Research For Rural Development. 12: 4.

Akter S and Uddin M (2009). Bangladesh poultry industry. J. Business and Technology. 4: 97-112.

BBS (2001). Statistical Pocket Book of Bangladesh, Bangladesh Bureau of Statistics, Ministry of Planning, Government of the Peoples Republic of Bangladesh, Dhaka.

Hauque S (2005). Status of broiler farming in Sherpur sadar upazilla. MS Thesis, Department of Poultry Science, BAU., Mymensingh.

Islam (2003). Demand projections for poultry products and poultry feeds in Bangladesh No. 54, MSSD discussion papers from Internatioal Food Policy Research Institute (IFPRI)

Jabber MA and Green DAG (1983). The status and potential of livestock within the contact of Agricultural Development Policies in Bangladesh, Aberysth the University College, Wales, UK, P. 156-190.

Karim MR (2001). Profitable analysis of broiler farming under contract farming system. MS Thesis, Department of Agricultural Economics and Rural Sociology, Bang. Agric. Uni., Mymensingh. P. 35-75.

Miah MTH (1990). Economics of commercial poultry farming in Bangladesh. Report No. 21, Bureau of Socio-Economic Research and Training, P. 135-190.

Perry J, Banker D and Green R (1999). Broiler farms organization, management and performance. Agricultural Information Bulletin, United States Department of Agriculture, No. 748.

Rahman M, Roy SK and Dey MS (2003). Production performance of two broiler strains as affected by season and rural environment of Bangladesh. Pakistan J. Biol. Sci. 6: 735-737.

Rahman MM, Islam MR, Ullah MN and Adeyl FMM (2002). Study on the scientific knowledge and management skill in commercial broiler farming program at the farmer level of Rajshahi district. On Line J. Biol. Sci. 2: 767-768.

Rahman WM (2004). Livestock and poultry rising as a poverty alleviation strategy in some selected area of Mymensingh. MS Thesis, Dept. Rural Sociology, Bang. Agric. Univ., Mymensingh, Bangladesh. P. 45-76.

Sharma RR (2003). A study on the constraints encountered by broiler farmers in Haryana. Ind. J. Poult. Sci. 38: 302-304. 